\title{
anatomy
}

\section{Effects of physical characteristics, exercise and smoking on morphometry of human Achilles tendon: an ultrasound study*}

\author{
Mustafa Canbolat ${ }^{1}$, Davut Özbağ ${ }^{1}$, Zeynep Özdemir ${ }^{2}$, Gökhan Demirtaş ${ }^{2}$ Armağan Şahin Kafkas ${ }^{3}$ \\ ${ }^{1}$ Department of Anatomy, School of Medicine, İnönii University, Malatya, Turkey \\ ${ }^{2}$ Department of Radiology, School of Medicine, Inönii University, Malatya, Turkey \\ ${ }^{3}$ School of Physical Education and Sports, İnönii University, Malatya, Turkey
}

\begin{abstract}
Objectives: The aim of this study was to reveal the normal morphometric values of Achilles tendon using ultrasound (US) imaging in subjects of different gender, age groups, smoking status, and physical exercise habits.

Methods: A total of 342 Achilles tendons were examined in the 171 volunteers (69 females, 102 males) with different age, gender, weight, height, smoking and physical exercise habits. Achilles tendon width, length, thickness, cross-sectional area and length were measured using a commercial ultrasound machine with a 9-15 $\mathrm{mHz}$ linear-array transducer.

Results: The average width, thickness, cross-sectional area and length of the Achilles tendon in male subjects were significantly higher than females. Tendon width, thickness, cross-sectional area and length showed no significant difference between the right and left side. With the exception of the left Achilles tendon thickness, measurements taken for non-smoking subjects were larger than smokers. Achilles tendon measurements of subjects engaged in sportive activities were significantly larger than those with sedentary lifestyle Weight and body mass index were the only anthropometric measurements in correlation with Achilles tendon size.
\end{abstract}

Conclusion: Achilles tendon size varies with age, gender, physical activity and smoking habits. The measurements presented in this study give normal variations of the tendon's morphologic characteristics, which will be of use in clinical diagnosis.

Keywords: Achilles tendon; anthropometry; exercise; smoking; ultrasound

Anatomy 2015;9(3):128-134 (2015 Turkish Society of Anatomy and Clinical Anatomy (TSACA)

\section{Introduction}

Achilles tendon is the largest, strongest and thickest tendon in the human body ${ }^{[1]}$ as a large and superficial structure that is easily accessible. ${ }^{[2]}$ Tendons, as connective tissues, transfer the force produced by muscles to bones. ${ }^{[3]}$ Achilles tendon may carry up to $110 \mathrm{MPa}$ during running ${ }^{[4]}$ playing a very important role in lower limb biomechanics. ${ }^{[5]}$ This tendon is amongst the most frequently damaged tendons in our body due to overuse and trau- ma. ${ }^{[1]}$ Tendon disorders result in imbalance between mobility and stability. In recent years, the number and incidence of tendon injuries have increased to account for $30 \%$ to $50 \%$ of all sports-related injuries. ${ }^{[6]}$

Changes in Achilles tendon size provide information on tendon health. For example, thickening of Achilles tendon is a precursor tendon ruptures. ${ }^{[7-10]}$ To determine the pathological changes for the size of Achilles tendon, it is necessary to to know the normal size. In this study, we aimed to reveal the normal morphometric values of

*This study was presented at the XXIV International Symposium on Morphological Sciences (ISMS), 2-6 September 2015, Istanbul, Turkey 
Achilles tendon using ultrasound (US) imaging in a normal population to investigate the size of Achilles tendon depending on variables such as age, sex, weight, height, smoking status, and engagement in sportive activities. Another aim of this study was to investigate the relationship between anthropometric measurements and Achilles tendon morphometry.

\section{Materials and Methods}

This study was performed on 342 Achilles tendons of 171 healthy adult volunteers (69 females, 102 males) with no prior history of orthopedic surgery, deformity, fracture and abnormality in the ankle area or any systematic disease. The Ethical Committee of İnönü University School of Medicine approved all protocols (Approval number 2014/114). Informed consent was obtained from all subjects. Information including age, gender, smoking status, dominant foot, and engagement in sportive activities were collected. One hundred of the subjects were non-smokers, 71 were smokers, 95 were engaged in sportive activities, and 76 did not regularly take part in any sportive activity. For all subjects, the dominant foot was the right foot.

Criteria to carry out regular sportive activities were determined as follows: Participating in heavy sportive activities for at least $20 \mathrm{~min} /$ day for 3 days/week or moderate sportive activities of at least $30 \mathrm{~min} /$ day for 5 days/week under the supervision of an expert coach. Participation in these activities should be for at least 6 months.

Subjects were considered to be current smokers if they smoke at least 100 cigarettes up to the recorded date and were still smoking or had quit smoking a short time ago, i.e. within the last 12 months. Non-smokers were defined as those who never smoked or smoked less than 100 cigarettes over the course of their life.

Anthropometric measurements of height, weight, body mass index (BMI), waist, hip and thigh circumference, total lower limb length, tibia length, knee, calf and ankle circumference, foot length and breadth were taken by the same researcher.

All sonographic examinations were performed using a commercial ultrasound system (General Electric, Waukesha, WI, USA) with a $9-15 \mathrm{mHz}$ linear-array transducer. To take normative measurements of the Achilles tendon, subjects lay in prone position with their feet hanging over the edge of the examination table. In order to increase the contact surface of the tendon and probe, the ankle was flexed up to $90^{\circ}$ and the footpad rested against the wall to maintain a vertical angle (Figure 1). All sonographic scans and measurements were performed bilaterally by the same radiologist. The thickness, width and cross-sectional area of the tendons were measured at the level of the medial malleolus in the transverse scan. The thickness and width were measured by the maximum anteroposterior and mediolateral diameter, respectively while the cross-sectional area was measured by the continuous trace method by marking the boundaries of the tendon (Figure 2).

IBM SPSS Statistics 22.0 for Windows (SPSS Inc., Chicago, IL, USA) was used for statistical analysis. The test of normality was approved by the Shapiro-Wilk test. Variables were submitted as median values (min-max)

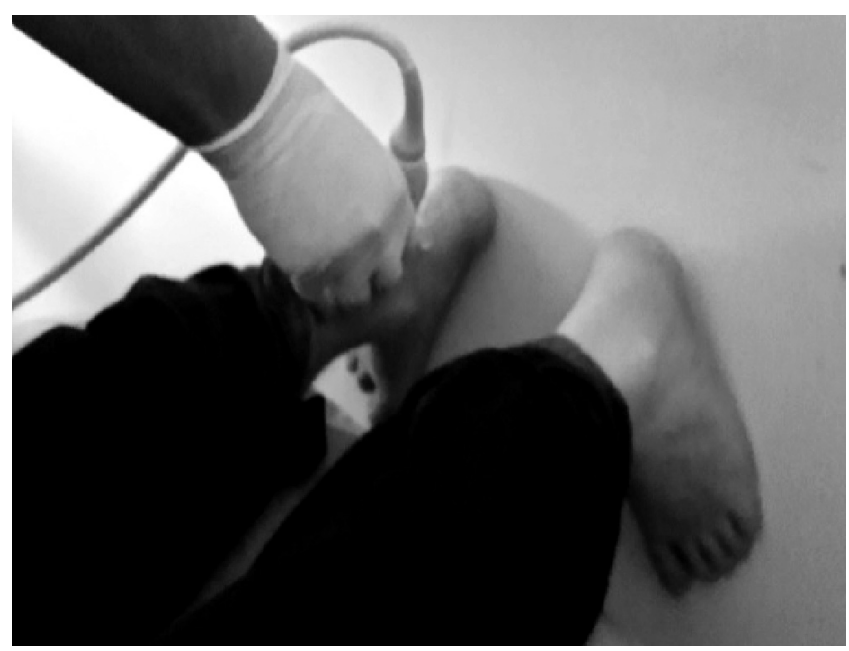

Figure 1. Position of the calf and ankle region in US examination.

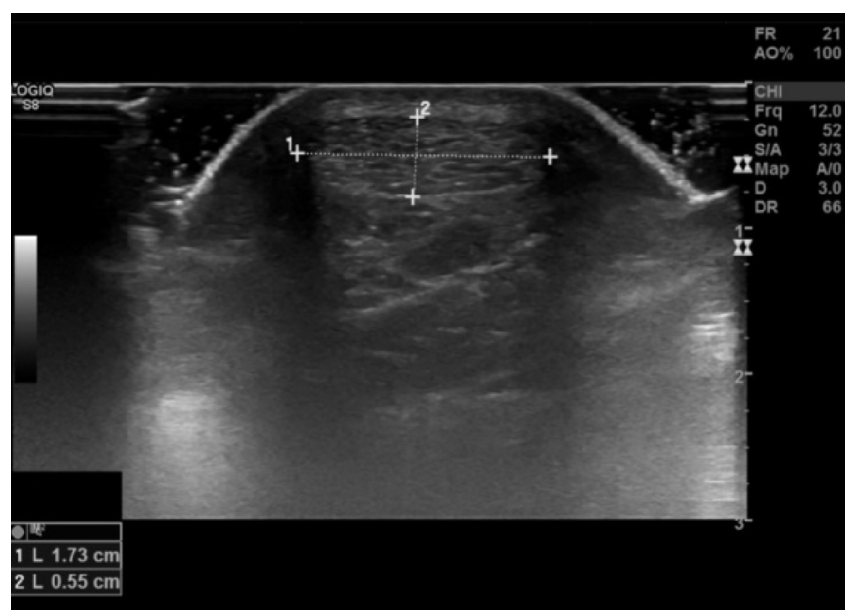

Figure 2. Measurement of Achilles tendon width, thickness and crosssectional area in US 
Table 1

Mean values of Achilles tendon width, thickness and cross-sectional area for males and females (Shapiro-Wilk test).

\begin{tabular}{|c|c|c|c|c|c|c|c|c|}
\hline Gender & $\begin{array}{l}\text { Right } \\
\text { width } \\
(\mathrm{mm})\end{array}$ & $\begin{array}{c}\text { Right } \\
\text { thickness } \\
(\mathrm{mm})\end{array}$ & $\begin{array}{l}\text { Right } \\
\text { area } \\
\left(\mathrm{mm}^{2}\right)\end{array}$ & $\begin{array}{c}\text { Right } \\
\text { length } \\
(\mathrm{mm})\end{array}$ & $\begin{array}{l}\text { Left } \\
\text { width } \\
(\mathrm{mm})\end{array}$ & $\begin{array}{l}\text { Left } \\
\text { thickness } \\
(\mathrm{mm})\end{array}$ & $\begin{array}{c}\text { Left } \\
\text { area } \\
\left(\mathrm{mm}^{2}\right)\end{array}$ & $\begin{array}{c}\text { Left } \\
\text { length } \\
(\mathrm{mm})\end{array}$ \\
\hline $\begin{array}{l}\text { Males } \\
(n=109)\end{array}$ & $\begin{array}{c}15.38 \\
(9.7-18.23)\end{array}$ & $\begin{array}{c}4.56 \\
(3.67-6)\end{array}$ & $\begin{array}{c}55 \\
(31-85)\end{array}$ & $\begin{array}{c}65.74 \\
(41.65-105.8)\end{array}$ & $\begin{array}{c}15.08 \\
(9.54-18.28)\end{array}$ & $\begin{array}{c}4.38 \\
(3.5-6.2)\end{array}$ & $\begin{array}{c}55 \\
(33-75)\end{array}$ & $\begin{array}{c}68.47 \\
(43.18-111.58)\end{array}$ \\
\hline $\begin{array}{l}\text { Females } \\
(n=62)\end{array}$ & $\begin{array}{c}13.31 \\
(10.18-15.5)\end{array}$ & $\begin{array}{c}4.09 \\
(3.14-5.84)\end{array}$ & $\begin{array}{c}44 \\
(33-68)\end{array}$ & $\begin{array}{c}56.96 \\
(42.06-108.14)\end{array}$ & $\begin{array}{c}13.17 \\
(10.19-15.22)\end{array}$ & $\begin{array}{c}4.03 \\
(3.02-5.44)\end{array}$ & $\begin{array}{c}43 \\
(31-59)\end{array}$ & $\begin{array}{c}54.35 \\
(41.36-90.19)\end{array}$ \\
\hline
\end{tabular}

based on the distribution. Mann-Whitney $U$ test was used for comparison of the two independent groups. Spearman's correlation analysis was utilized to determine the relationship between Achilles tendon measurements and anthropometric measurements. For age group comparisons, owing to non-normal distributed data, Kruskal-Wallis test was used for comparing four different age groups. Multiple comparisons were carried out by Conover test.

\section{Results}

The average values of Achilles tendon measurements and anthropometric measurements for males and females are shown in Tables $\mathbf{1}$ and $\mathbf{2}$. The average tendon width, thickness, cross-sectional area and length of male subjects were significantly higher than the average for female subjects $(\mathrm{p}<0.05$, Table 3$)$. Achilles tendon width, thickness, area and length showed no significant differences between the right and left side tendons (Table 4).

For the measurements of Achilles tendon in smokers and non-smokers, with the exception of the left Achilles tendon thickness, measurements taken for non-smoking subjects were larger than smokers $(\mathrm{p}<0.05)$ (Table 5). Achilles tendon measurements of subjects engaged in sportive activities were significantly larger than those with sedentary lifestyle (Table 6).

The subjects were divided to age groups 18-29, 30-39, 40-49 and 50-50+. The width of the Achilles tendon on the left side, and the length on both the right and left sidea were measured as significantly smaller in the age group 18-29 when compared to age groups 30-39, 40-49, and 50-50+) (Table 7).

No strong correlation was found between Achilles tendon measurements and anthropometric measurements. Only weight and BMI showed good correlation with tendon sizes. Other anthropometric measurements had poor or very poor correlations with tendon sizes. The highest correlation value was between the weight and cross-sectional area of left Achilles tendon's $(\mathrm{r}=0.588, \mathrm{p}<0.000)$.

\section{Discussion}

Performed with substantially more subjects (on 342 Achilles tendons) than earlier studies, the results of this study provide new information about normal Achilles tendon morphology. Interestingly, it was observed that ethnic factors affected Achilles tendon size, so this study will provide information specific for Turkish population. ${ }^{[2]}$

In this study, we have used ultrasonography for measurements. Magnetic resonance imaging can give more detailed results; ${ }^{[11]}$ but, US imaging has advantages in being non-invasive, cheap, safe (no radiation danger), quick and easily available. The high acoustic contrast of tendons makes them suitable for sonographic assessments. ${ }^{[12]}$ Sonography also allows for dynamic examina-

Table 2

Anthropometric values for males and females.

\begin{tabular}{|c|c|c|c|c|c|c|c|c|c|c|c|c|c|c|}
\hline Gender & Age & $\begin{array}{l}\text { Height } \\
(\mathrm{cm})\end{array}$ & $\begin{array}{l}\text { Weight } \\
\text { (kg) }\end{array}$ & $\begin{array}{l}\text { WC } \\
(\mathrm{cm})\end{array}$ & BMI & $\begin{array}{l}\mathrm{HC} \\
(\mathrm{cm})\end{array}$ & $\begin{array}{l}\text { TLLL } \\
(\mathbf{c m})\end{array}$ & $\begin{array}{c}\text { TC } \\
(\mathrm{cm})\end{array}$ & $\begin{array}{l}\mathrm{TL} \\
(\mathrm{cm})\end{array}$ & $\begin{array}{l}\mathrm{KC} \\
(\mathrm{cm})\end{array}$ & $\begin{array}{c}\mathrm{CC} \\
(\mathrm{cm})\end{array}$ & $\begin{array}{c}\mathrm{AC} \\
(\mathrm{cm})\end{array}$ & $\begin{array}{c}\mathrm{FL} \\
(\mathrm{cm})\end{array}$ & $\begin{array}{l}\mathrm{FB} \\
(\mathrm{cm})\end{array}$ \\
\hline Males $(n=109)$ & 27.96 & 177.4 & 80.19 & 91.88 & 25.44 & 100.19 & 99.26 & 48.93 & 45.82 & 38.27 & 37.35 & 25.5 & 26.57 & 10.59 \\
\hline Females $(n=109)$ & 25.1 & 164.85 & 58.28 & 79.34 & 21.51 & 96.24 & 93.93 & 52.02 & 44.22 & 36.51 & 35.20 & 23.99 & 23.87 & 9.63 \\
\hline
\end{tabular}

AC: ankle circumference; BMI: body mass index; CC: calf circumference; FB: foot breadth; FL: foot length; HC: hip circumference; TC: thigh circumference; TLLL: total lower limb length; WC: waist circumference. 
Table 3

Comparison of the width, thickness and cross-sectional area of Achilles tendon on the right and left side for male and females using Mann-Whitney U test.

\begin{tabular}{|c|c|c|c|c|c|c|c|c|}
\hline Gender & $\begin{array}{l}\text { Right } \\
\text { width } \\
(\mathrm{mm})\end{array}$ & $\begin{array}{c}\text { Right } \\
\text { thickness } \\
\text { (mm) }\end{array}$ & $\begin{array}{l}\text { Right } \\
\text { area } \\
\left(\mathrm{mm}^{2}\right)\end{array}$ & $\begin{array}{l}\text { Right } \\
\text { length } \\
(\mathrm{mm})\end{array}$ & $\begin{array}{c}\text { Left } \\
\text { width } \\
(\mathrm{mm})\end{array}$ & $\begin{array}{l}\text { Left } \\
\text { thickness } \\
\text { (mm) }\end{array}$ & $\begin{array}{l}\text { Left } \\
\text { area } \\
\left(\mathrm{mm}^{2}\right)\end{array}$ & $\begin{array}{c}\text { Left } \\
\text { length } \\
(\mathrm{mm})\end{array}$ \\
\hline Males $(n=109)$ & 15.38 & 4.56 & 55 & 65.74 & 15.08 & 4.38 & 55 & 68.47 \\
\hline Females $(n=62)$ & 13.31 & 4.09 & 44 & 56.96 & 13.17 & 4.03 & 43 & 54.35 \\
\hline$p$ & $<0.0001$ & $<0.0001$ & $<0.0001$ & 0.004 & $<0.0001$ & $<0.0001$ & $<0.0001$ & $<0.0001$ \\
\hline
\end{tabular}

tion with real time feed-back. ${ }^{[12,13]}$ For these reasons we preferred US imaging and subjects readily adapted to the imaging technique.

Our findings show that males have significantly higher values than females for Achilles tendon size measurements (tendon width, length, thickness and cross-sectional area). To date, information in the literature has mostly focused on tendon thickness. An Achilles tendon thickness of $6 \mathrm{~mm}$ isconsidered the upper limit, but this may vary with anatomical and ethnic differences. ${ }^{[2]}$ Our findings for Achilles tendon thickness are around $4 \mathrm{~mm}$. Van Schie et al. ${ }^{[14]}$ measured Achilles tendon thickness as $6.8 \pm 1.2 \mathrm{~mm}$, Fahlstrom and Alfredson ${ }^{[15]}$ measuring $6 \pm 1$ $\mathrm{mm}$, Mabuchi et al. ${ }^{[16]} 6.03 \pm 0.2 \mathrm{~mm}$, Pang and Ying ${ }^{[17]}$ $5.1 \pm 0.6 \mathrm{~mm}$, and Kallinen and Suomin ${ }^{[18]} 5.7 \pm 1.4 \mathrm{~mm}$. There are differences in Achilles tendon sizes between males and females, possibly due to differences in muscle strength and mechanical properties. ${ }^{[19]}$ The difference may also be associated with the differences of calf muscle thickness between males and females ${ }^{[20]}$ or may originate from the differences in hormones. In women, the amount of estradiol, a form of estrogen, has been shown to affect tendon size. ${ }^{[21]}$

This study found no differences between the right and left side for all measurements. Bohm et al. ${ }^{[22]}$ showed the dominant foot's Achilles tendon length was signifi-
Table 4

Comparison of width, thickness and cross-sectional area of Achilles tendons of the left and right sides using Mann-Whitney $U$ and Wilcoxon $\mathrm{W}$ tests.

\begin{tabular}{lcccc}
\hline & Width & Thickness & Area & Length \\
\hline Mann-Whitney U & 13342 & 13547,5 & 14022 & 14376 \\
Wilcoxon W & 28048 & 28253,5 & 28728,000 & 29082 \\
Z & -1.398 & -1.174 & -0.655 & -0.267 \\
p & 0.162 & 0.240 & 0.512 & 0.789 \\
\hline
\end{tabular}

cantly longer than the non-dominant foot. Also, they found the thickness was significantly different between the dominant and non-dominant sides. Egwu et al. ${ }^{[23]}$ measured the left Achilles tendon thickness was greater than the right side. Pang and Ying ${ }^{[17]}$ observed that the length of Achilles tendon differed between the dominant and non-dominant side. Balius et al. ${ }^{[24]}$ found the same results on cadavers.

There was a significant difference for Achilles tendon measurements between those engaged in sportive activities versus those who were sedentary. Our findings are consistent with those of Egwu et al., ${ }^{[25]}$ Mathieson et al. ${ }^{[26]}$ and Civeira et al. ${ }^{[27]}$ Microtears and degeneration occurs in tendons due to overuse and exposure to repetitive trauma. Following this, a repair process starts. However,

Table 5

Measurements of right and left Achilles tendons for smokers and non-smokers (Mann-Whitney $\mathrm{U}$ test).

\begin{tabular}{|c|c|c|c|c|c|c|c|c|}
\hline $\begin{array}{l}\text { Groups } \\
\text { (Smoking) }\end{array}$ & $\begin{array}{l}\text { Right } \\
\text { width } \\
(\mathrm{mm})\end{array}$ & $\begin{array}{c}\text { Left } \\
\text { width } \\
(\mathrm{mm})\end{array}$ & $\begin{array}{l}\text { Right } \\
\text { thickness } \\
(\mathrm{mm})\end{array}$ & $\begin{array}{l}\text { Left } \\
\text { thickness } \\
(\mathrm{mm})\end{array}$ & $\begin{array}{l}\text { Right } \\
\text { length } \\
(\mathrm{mm})\end{array}$ & $\begin{array}{l}\text { Left } \\
\text { length } \\
(\mathrm{mm})\end{array}$ & $\begin{array}{l}\text { Right } \\
\text { area } \\
\left(\mathrm{mm}^{2}\right)\end{array}$ & $\begin{array}{l}\text { Left } \\
\text { area } \\
\left(\mathrm{mm}^{2}\right)\end{array}$ \\
\hline Non-smokers $(n=100)$ & 15.2 & 14.65 & 4.44 & 4.3 & 65.74 & 70.01 & 54 & 54 \\
\hline Smokers $(n=71)$ & 14.25 & 14.01 & 4.26 & 4.2 & 59.54 & 55.78 & 49 & 48 \\
\hline$p$ & $<0.0001$ & 0.001 & 0.001 & 0.155 & 0.021 & $<0.0001$ & $<0.0001$ & 0.002 \\
\hline
\end{tabular}


Table 6

Left and right sides measurements of volunteers engaged in sportive and sedentery subjects (Mann- Whitney $U$ test).

\begin{tabular}{|c|c|c|c|c|c|c|c|c|}
\hline Groups & $\begin{array}{l}\text { Right } \\
\text { width } \\
(\mathrm{mm})\end{array}$ & $\begin{array}{l}\text { Left } \\
\text { width } \\
(\mathrm{mm})\end{array}$ & $\begin{array}{c}\text { Right } \\
\text { thickness } \\
(\mathrm{mm})\end{array}$ & $\begin{array}{c}\text { Left } \\
\text { thickness } \\
(\mathrm{mm})\end{array}$ & $\begin{array}{c}\text { Right } \\
\text { length } \\
(\mathrm{mm})\end{array}$ & $\begin{array}{c}\text { Left } \\
\text { length } \\
(\mathrm{mm})\end{array}$ & $\begin{array}{l}\text { Right } \\
\text { area } \\
\left(\mathrm{mm}^{2}\right)\end{array}$ & $\begin{array}{c}\text { Left } \\
\text { area } \\
\left(\mathrm{mm}^{2}\right)\end{array}$ \\
\hline Sportive $(n=95)$ & 15.2 & 14.9 & 4.45 & 4.32 & 67.1 & 70.87 & 54 & 54 \\
\hline Sedenteries $(n=76)$ & 14.03 & 13.83 & 4.26 & 4.14 & 57.08 & 55.17 & 48 & 46 \\
\hline$p$ & $<0.0001$ & $<0.0001$ & 0.002 & 0.003 & $<0.0001$ & $<0.0001$ & $<0.0001$ & $<0.0001$ \\
\hline
\end{tabular}

if the tendon continues to strain excessively, the number of micro-tears increases. If this process is repeated consistently again and again tendon hypertrophy occurs. ${ }^{[28-30]}$ Regular exercise also results in tendon hypertrophy. ${ }^{[1,32]}$

Achilles tendon measurements were significantly higher in non-smokers compared to smokers. Cigarette smoking cause microvascular disorders in all tissues, ${ }^{[3,34]}$ so can disrupt tendon perfusion. Type 1 collagen is the main collagen in normal tendons. ${ }^{[35]}$ When the blood supply to the Achilles tendon decreases due to smoking, tendons can be damaged more easily. After injury, resynthesized collagen is Type III collagen. ${ }^{[3]}$ Jorgensen et al. ${ }^{[3]}$ showed that non-smokers had a 1.8 times higher amount of mature collagen in their surgical wounds. Tendons with abnormal collagen composition have abnormal structure. There is an inverse relationship between type III collagen and fibril diameter in the tendon, ${ }^{[38]}$ and the difference may be due to these reasons.

The width of the Achilles tendon on the left side, and the length on both the right and left sides were significantly smaller in the age group 18-29 when compared to other age groups (30-39, 40-49, and 50-50+). Stenroth et al. ${ }^{[39]}$ showed that tendon cross-sectional area was $16 \%$ larger in the older groups. Magnusson et al. ${ }^{[40]}$ found larger Achilles tendon cross-sectional area in old women when compared to the young. The course of a lifetime brings more exposure to trauma, and we know the repair process results in hypertrophy. Kinugasa et al. ${ }^{[4]}$ found a significant increase in Achilles tendon volume after 4 weeks of unloading. Forces acting on the tendon are reduced in the elderly due to decreased physical activity. Another possible theory that explains this hypertrophy is high blood cholesterol levels in old population. The clinical features of familial hypercholesterolemia include tendon xanthomas and the Achilles tendon is the usual location of these xanthomas which result in hypertrophy in tendon structure.

\section{Conclusion}

Sonography is a useful imaging tool for morphometric measurements of Achilles tendon. This comprehensive study presenting normal values of the Achilles tendon and changes in tendon measurements related to physical characteristics, exercise and smoking provides better understanding of the morphologic characteristics of normal Achilles tendons, which may help for a more accurate diagnosis in US.

Table 7

Achilles tendon measurements of right and left side Achilles tendons for different age groups (Mann-Whitney $U$ test). Comparison was made for age group 18-29 to the 30-39, 40-49 and 50-50+ age groups.

\begin{tabular}{|c|c|c|c|c|c|c|c|c|}
\hline $\begin{array}{l}\text { Groups } \\
\text { (Age range) }\end{array}$ & $\begin{array}{l}\text { Right } \\
\text { width } \\
(\mathrm{mm})\end{array}$ & $\begin{array}{l}\text { Left } \\
\text { width } \\
(\mathrm{mm})\end{array}$ & $\begin{array}{c}\text { Right } \\
\text { thickness } \\
(\mathrm{mm})\end{array}$ & $\begin{array}{l}\text { Left } \\
\text { thickness } \\
(\mathrm{mm})\end{array}$ & $\begin{array}{c}\text { Right } \\
\text { length } \\
(\mathrm{mm})\end{array}$ & $\begin{array}{c}\text { Left } \\
\text { length } \\
(\mathrm{mm})\end{array}$ & $\begin{array}{c}\text { Right } \\
\text { area } \\
\left(\mathrm{mm}^{2}\right)\end{array}$ & $\begin{array}{l}\text { Left } \\
\text { area } \\
\left(\mathrm{mm}^{2}\right)\end{array}$ \\
\hline $18-29(n=131)$ & 14.67 & 14.22 & 4.32 & 4.2 & 60.12 & 58.86 & 51 & 49 \\
\hline $30-39 \quad(n=20)$ & 15.64 & 15.29 & 4.59 & 4.3 & 70.81 & 72.21 & 57 & 55 \\
\hline 40-49 $(n=9)$ & 15.04 & 14.79 & 4.33 & 4.5 & 69 & 70.33 & 49 & 58 \\
\hline $50-50+(n=11)$ & 14.73 & 14.65 & 4.44 & 4.32 & 78.71 & 81.56 & 53 & 58 \\
\hline $\mathrm{p}$ & 0.326 & 0.04 & 0.275 & 0.556 & $<0.0001$ & $<0.0001$ & 0.273 & 0.05 \\
\hline
\end{tabular}




\section{References}

1. Schweitzer ME, Karasick D. MR imaging of disorders of the Achilles tendon. AJR Am J Roentgenol 2000;175:613-25.

2. Koivunen-Niemelä T, Parkkola K. Anatomy of the Achilles tendon (tendo calcaneus) with respect to tendon thickness measurements. Surg Radiol Anat 1995;17:263-8.

3. Levangie P, Norkin C. Joint structure and function: a comprehensive analysis. 5th ed. New Delhi; Jaypee Brothers; 2011. Chapter 12, The ankle and foot complex; p. 440-82.

4. Maffuli N, Almekinders LC. The Achilles tendon. London: Springer-Verlag; 2007. p. 36.

5. Apaydın N, Ünlü S, Bozkurt M, Doral MN. Functional anatomy and biomechanical aspects of the Achilles tendon. [Article in Turkish] TOTBID Dergisi 2011;10:61-8.

6. Mow VC, Huiskes R. Basic orthopaedic biomechanics and mechanobiology. Philadelphia: Lippincott Williams and Wilkins; 2005. p. 301-41.

7. Fredberg U, Bolvig L, Andersen NT, Stengaard-Pedersen K. Ultrasonography in evaluation of Achilles and patella tendon thickness. Ultraschall Med 2008;29:60-5.

8. Nehrer S, Breitenseher M, Brodner W, Kainberger F, Fellinger EJ, Engel A, Imhof F. Clinical and sonographic evaluation of the risk of rupture in the Achilles tendon. Arch Orthop Trauma Surg 1997;116:14-8.

9. Järvinen TA, Järvinen TL, Kannus P, Józsa L, Järvinen M. Collagen fibres of the spontaneously ruptured human tendons display decreased thickness and crimp angle. J Orthop Res 2004;22:1303-9.

10. Eriksen HA, Pajala A, Leppilahti J, Risteli J. Increased content of type III collagen at the rupture site of human Achilles tendon. J Orthop Res 2002;20:1352-7.

11. Karjalainen PT, Soila K, Aronen HJ, Pihlajamäki HK, Tynninen O, Pavonen T, Tirman PF. MR imaging of overuse injuries of the Achilles tendon. AJR Am J Roentgenol 2000;175:251-60.

12. O'Connor PJ, Grainger AJ, Morgan SR, Smith KL, Waterton JC, Nash AF. Ultrasound assessment of tendons in asymptomatic volunteers: a study of reproducibility. Eur Radiol 2004;14:1968-73.

13. Grassi W, Filippucci E, Farina A, Cervini C. Sonographic imaging of tendons. Arthritis Rheum 2000;43:969-76.

14. van Schie HT, de Vos RJ, de Jonge S, Bakker EM, Heijboer MP, Verhaar JA, Tol JL, Weinans H. Ultrasonographic tissue characterisation of human Achilles tendons: quantification of tendon structure through a novel non-invasive approach. Br J Sports Med 2010;44:1153-9.

15. Fahlström M, Alfredson H. Ultrasound and Doppler findings in the Achilles tendon among middle-aged recreational floor-ball players in direct relation to a match. Br J Sports Med 2010;44:140- 3.

16. Mabuchi H, Tatami R, Haba T, Ueda K, Ueda R, Ito S, Karnetani T, Koizurni J, Miyamoto S, Ohta M, Takeda R, Takegoshi T, Takeshita H. Achilles tendon thickness and ischemic heart disease in familial hypercholesterolemia. Metabolism 1978;27:1672-9.

17. Pang BS, Ying M. Sonographic measurement of achilles tendons in asymptomatic subjects: variation with age, body height, and dominance of ankle. J Ultrasound Med 2006;25:1291-6.

18. Kallinen M, Suominen H. Ultrasonographic measurements of the Achilles tendon in elderly athletes and sedentary men. Acta Radiol 1994;35:560-3.
19. Muraoka T, Muramatsu T, Fukunaga T, Kanehisa H. Elastic properties of human Achilles tendon are correlated to muscle strength. J Appl Physiol (1985) 2005;99:665-9.

20. Egwu O, Njoku CO, Ukoha UU, Eteudo AN, Elem BC. Calf muscle (triceps surae complex) thickness in an adult Nigerian population: an imaging based normographic study. Macedonian Journal of Medical Sciences 2013;6:146-52.

21. Finni T, Kovanen V, Ronkainen PH, Pöllänen E, Bashford GR, Kaprio J, Alén M, Kujala UM, Sipilä S. Combination of hormone replacement therapy and high physical activity is associated with differences in Achilles tendon size in monozygotic female twin pairs. J Appl Physiol (1985) 2009;106:1332-7.

22. Bohm S, Mersmann F, Marzilger R, Schroll A, Arampatzis A. Asymmetry of Achilles tendon mechanical and morphological properties between both legs. Scand J Med Sci Sports 2015;25: e124-32.

23. Egwu OA, Ogbonna CO, Salami E, Eni OE, Besong E, Onwe CC. Normal thickness of the tendo calcaneus (TCT) in an adult Nigerian population: an imaging based normographic study. Br J Med Med Res 2014;4:2100-11.

24. Balius R, Alomar X, Rodas G, Miguel-Pérez M, Pedret C, Dobado MC, Blasi J, Koulouris G. The soleus muscle: MRI, anatomic and histologic findings in cadavers with clinical correlation of strain injury distribution. Skeletal Radiol 2013;42:521-30.

25. Egwu OA, Anibeze CIP, Akpuaka FC, Udoh BE. Activity related differences in the thickness of achilles tendon among four different occupational groups in nigeria: an ultrasound based study. Bangladesh J Med Sci 2012;11:103-11.

26. Mathieson JR, Connell DG, Cooperberg PL, Lloyd-Smith DR. Sonography of the Achilles tendon and adjacent bursae. AJR Am J Roentgenol 1988;151:127-31.

27. Civeira F, Castillo JJ, Calvo C, Ferrando J, de Pedro C, MartínezRodés P, Pocoví M. Achilles tendon size by high resolution sonography in healthy population. Relationship with lipid levels. Med Clin (Barc) 1998;111:41-4.

28. Cook JL, Khan KM, Harcourt PR, Kiss ZS, Fehrmann MW, Griffiths L, Wark JD. Patellar tendon ultrasonography in asymptomatic active athletes reveals hypoechoic regions: a study of 320 tendons. Victorian Institute of Sport Tendon Study Group. Clin J Sport Med 1998;8:73-7.

29. Cook JL, Khan KM, Kiss ZS, Coleman BD, Griffiths L. Asymptomatic hypoechoic regions on patellar tendon ultrasound: A 4-year clinical and ultrasound followup of 46 tendons. Scand J Med Sci Sports 2001;11:321-7.

30. Cook JL, Khan KM, Kiss ZS, Purdam CR, Griffiths L. Prospective imaging study of asymptomatic patellar tendinopathy in elite junior basketball players. J Ultrasound Med 2000;19:473-9.

31. Kongsgaard M, Aagaard P, Kjaer M, Magnusson SP. Structural Achilles tendon properties in athletes subjected to different exercise modes and in Achilles tendon rupture patients. J Appl Physiol 2005;99:1965-71.

32. Rosager S, Aagaard P, Dyhre-Poulsen P, Neergaard K, Kjaer M, Magnusson SP. Load-displacement properties of the human triceps surae aponeurosis and tendon in runners and non-runners. Scand J Med Sci Sports 2002;12:90-8.

33. Unal B, Bilgili MYK, Yılmaz S, Caglayan O, Kara S. Smoking prevents the expected postprandial increase in intestinal blood flow. J Ultrasound Med 2004;23:647-53. 
34. Jacobovicz J, Tolazzi AR, Timi JR. Doppler ultrasound evaluation of facial transverse and infraorbital arteries: influence of smoking and aging process. Aesthetic Plast Surg 2007;31:526-31.

35. Maffulli N, Ewen SW, Waterston SW, Reaper J, Barrass V. Tenocytes from ruptured and tendinopathic achilles tendons produce greater quantities of type III collagen than tenocytes from normal achilles tendons. An in vitro model of human tendon healing. Am J Sports Med 2000;28:499-505.

36. Whittaker P, Canham PB. Demonstration of quantitative fabric analysis of tendon collagen using two-dimensional polarized light microscopy. Matrix 1991;11:56-62.

37. Jorgensen LN, Kallehave F, Christensen E, Siana JE, Gottrup F. Less collagen production in smokers. Surgery 1998;12:450-5.
38. Birk DE, Mayne R. Localization of collagen types I, III and V during tendon development. Changes in collagen types I and III are correlated with changes in fibril diameter. Eur J Cell Biol 1997;72: 352-61.

39. Stenroth L, Peltonen J, Cronin NJ, Sipilä S, Finni T. Age-related differences in Achilles tendon properties and triceps surae muscle architecture in vivo. J Appl Physiol (1985) 2012;113:1537-44.

40. Magnusson SP, Beyer N, Abrahamsen H, Aagaard P, Neergaard $\mathrm{K}$, Kjaer M. Increased cross-sectional area and reduced tensile stress of the Achilles tendon in elderly compared with young women. J Gerontol A Biol Sci Med Sci 2003;58:123-7.

41. Kinugasa R, Hodgson JA, Edgerton VR, Shin DD, Sinha S. Reduction in tendon elasticity from unloading is unrelated to its hypertrophy. J Appl Physiol (1985) 2010;109:870-7.

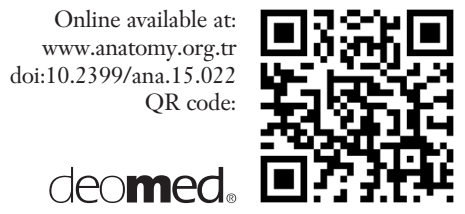

Correspondence to: Mustafa Canpolat

Department of Anatomy, School of Medicine,

Inönü University, Malatya, Turkey

Phone: +90 5056682547

e-mail: mcanpolat1907@yahoo.com

Conflict of interest statement: No conflicts declared.

This is an open access article distributed under the terms of the Creative Commons Attribution-NonCommercial-NoDerivs 3.0 Unported (CC BY-NCND3.0) Licence (http://creativecommons.org/licenses/by-nc-nd/3.0/) which permits unrestricted noncommercial use, distribution, and reproduction in any medium, provided the original work is properly cited. Please cite this article as: Canbolat M, Özbağ D, Özdemir Z, Demirtaş G, Şahin Kafkas A. Effects of physical characteristics, exercise and smoking on morphometry of human Achilles tendon: an ultrasound study. Anatomy 2015;9(3):128-134. 